\section{DOES DOMESTIC PRIVATE INVESTMENT INDUCE ENVIRONMENTAL DAMAGE IN TURKEY? EVIDENCE FROM FOURIER-BASED METHODS ${ }^{1}$}

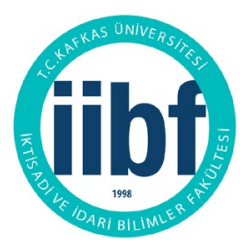

Kafkas University Faculty of Economics and Administrative Sciences KAUJEASF

Vol. 12, Issue 23, 2021
ISSN: $1309-4289$

E - ISSN: 2149 - 9136
Alper KARASOY

Res. Ass. Dr.

Afyon Kocatepe University

Faculty of Economics and

Administrative Sciences

Afyonkarahisar, Turkey

akarasoy@aku.edu.tr

ORCID: 0000-0001-9447-3375 aspects of domestic private investment (DPRI) have been empirically studied in the literature, evidence regarding the effect of DPRI on environmental sustainability is rather nascent. This research attempts to fill this gap by investigating how DPRI in Turkey affected environmental degradation (namely ecological and carbon footprints) for the 1975-2017 period by employing Fourier-based approaches. The findings in this research indicate that employed variables (environmental degradation, income, energy use, and DPRI) have a long-run association in both proposed models. Furthermore, the dynamic relationship captured by the autoregressive distributed lag (ARDL) method shows that DPRI and primary energy use induce ecological and carbon footprints in the long-run. At the same time, income intensifies both environmental degradation indicators in the short-run. These results indicate that DPRI threatens Turkey's long-term environmental sustainability.

Keywords: Turkey, domestic private investment, Fourier-based methods.

JEL Codes: C500, E220, Q560

Scope: Economics

Type: Research

DOI: 10.36543/kauiibfd.2021.004

Cite this Paper: Karasoy, A. (2021). Does domestic private investment induce environmental damage in Turkey? Evidence from Fourier-based methods. KAÜIIIBFD, 12(23), 55-76.

\footnotetext{
${ }^{1}$ Compliance with the ethical rules of the relevant study has been declared.
} 


\section{TÜRKİYE'DEKİ ÖZEL YATIRIMLAR CCEVRESEL BOZULMAYI TETIKLIYOR MU? FOURIER TEMELLİ YÖNTEMLER ÜZERİNDEN BİR KANIT}

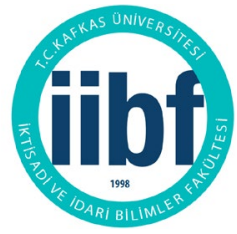

Kafkas Üniversitesi Íktisadi ve İdari Bilimler Fakültesi KAÜIİBFD

Cilt, 12, Say1 23, 2021

ISSN: $1309-4289$

E - ISSN: 2149-9136

\author{
Alper KARASOY \\ Arş. Gör. Dr. \\ Afyon Kocatepe Üniversitesi \\ İktisadi ve İdari Bilimler Fakültesi \\ Afyonkarahisar, Türkiye \\ akarasoy@aku.edu.tr
}

ORCID: 0000-0001-9447-3375

\section{ÖZ Her ne kadar yurtiçi özel} yatırımların (YÖY) farklı boyutları literatürde ampirik olarak incelenmiş olsa da YÖY'ün çevresel sürdürülebilirliğe olan etkisini inceleyen çalışma sayısı son derece sınırlıdır. Bu araştırmada, YÖY'ün Türkiye'deki çevresel bozulma göstergelerini (ekolojik ve karbon ayak izlerini) nasıl etkilediği 1975-2017 dönemi için ve Fourier temelli yöntemler kullanılarak incelenmiştir. Bu araştırmanın sonuçlarına göre, ileri sürülmüş olan her iki modelde de kullanılmış olan değişkenlerin (çevresel bozulma, gelir, enerji tüketimi ve YÖY) uzun dönemde birlikte hareket ettiği bulunmuştur. Ayrıca kendiyle bağlanımlı dağıtılmış gecikmeli (ARDL) yöntemle tespit edilmiş olan dinamik ilişkilere göre; YÖY ve birincil enerji tüketiminin uzun dönemde hem ekolojik ayak izini hem de karbon ayak izini arttırdığ de kısa dönemde çevresel bozulmayı arttırdığı tespit edilmiştir. Elde edilen sonuçlar YÖY'ün Türkiye'nin uzun dönem çevresel sürdürülebilirliğini tehdit ettiğini göstermektedir.

Anahtar Kelimeler: Türkiye, yurtiçi özel yatırımlar, Fourier temelli yöntemler.

JEL Kodlart: C500, E220, Q560

Alan: Iktisat

Türü: Araştırma 


\section{INTRODUCTION}

While domestic investment is shown to be conducive for growth (see Ikpesu et al., 2019), some empirical studies claim that compared to its public and foreign counterparts, domestic private investment (DPRI) is more effective in fostering economic growth, particularly in developing countries (see Khan \& Reinhart, 1990; Makuyana \& Odhiambo, 2019; Shabbir et al., 2020; Zou, 2006). As DPRI's significance for economic growth is evident, there exists extant literature on the determinants of DPRI for different developing countries, including Turkey (see Akçay \& Karasoy, 2020; Ayeni, 2020; Güney, 2020; Ismihan et al., 2005; Sallam, 2019).

However, the number of studies investigating the environmental impacts of DPRI is rather limited, and these studies use a limited environmental damage indicator that is carbon dioxide emissions (see the literature review section). Further, to the best of the author's knowledge, DPRI's effect on Turkey's environmental sustainability has never been investigated. Examining the impact that DPRI creates on Turkey's environmental sustainability may provide new perspectives in combating the environmental issues in Turkey. In this regard, as figure 1 clearly indicates, DPRI constitutes a significant part of the Turkish economy; for instance, it increased from $14.8 \%$ in 1975 to more than $25 \%$ (as a share of GDP) in 2017. In parallel with this rise, both ecological and carbon footprints in Turkey also significantly increased. For example, compared to the 1975 value, Turkey's ecological footprint per person in 2017 increased by almost $70 \%$. More impressively, Turkey's carbon footprint, a sub-component of ecological footprint, also grew by more than $209 \%$ (increased from 0.72 global hectares (gha) in 1975 to 2.23 gha in 2017). The same figure also shows an evident co-movement among these variables as well, implying a long-run association between them. 


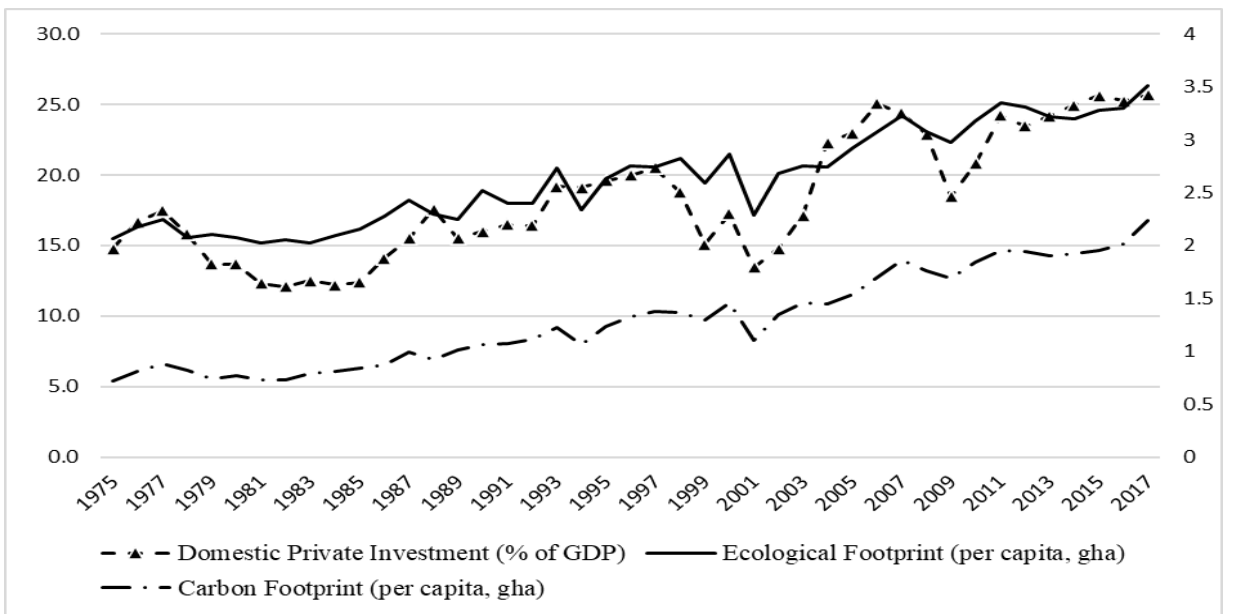

Figure 1: Trends for Turkey's DPRI, Ecological and Carbon Footprints

Notes: Data sources are shown in Table 1. The left axis shows DPRI; the right axis shows ecological and carbon footprints. GDP: gross domestic product, gha: global hectares.

Accordingly, this research attempts to empirically examine if there is a co-movement between DPRI and environmental degradation (proxied by ecological and carbon footprints) and whether DPRI played a role in inducing environmental damage in Turkey. In this attempt, the Fourier augmented unitroot, and cointegration (CI) tests and the autoregressive distributed lag (ARDL) method are employed. As also summarized in the methods section, the main reason for employing the Fourier approximated tests is to account for structural shifts that might have affected the selected time series and their cointegrating properties. Besides for robustness check, the ARDL bounds testing procedure is utilized to reveal the dynamic impacts that DPRI and other selected independent variables (GDP and primary energy use per capita) have on the selected environmental damage indicators (ecological and carbon footprints).

This research is designed as follows: the next section presents the concepts regarding the DPRI-environment nexus and the summary of the literature. The third section describes the utilized data, models, and methods. The fourth section presents the findings, and the last section concludes the research. 


\section{SUMMARY OF CONCEPTS AND LITERATURE}

The environmental impact of DPRI is initially conceptualized relative to public investment's impact. In this regard, supporters of private enterprises claim that, unlike public enterprises, DPRI seeks efficiency. As a result, private investors tend to devote more sources to novel and environmentally friendly technology, which can help to curb environmental damage. Further, it can be much harder for DPRI to avoid environmental requirements because compared to the public sector's liaisons with the state authorities, private investors' relationships with these authorities are relatively weak, and DPRI usually receives more pressure from government authorities with regards to complying with environmental measures. Lastly, unlike public sector investment, DPRI can also be forced by private financial and capital bodies to adhere to environmental requirements (Talukdar \& Meisner, 2001: 829-830).

Adversaries of DPRI who propound that the private sector is harmful to the environment make the following claims: First, contrary to the public sector, competitive pressures and revenue and/or profit-related concerns are much more relevant in the private sector. Thus, this can push the DPRI to take more polluting (economic) activities to reach these goals and/or stay competent. Second, the private sector tends to have more liquidity than its public counterpart; private investors can entice government officials to circumvent environmental controls by using this liquidity. Third, executives of DPRI can conceal data about their polluting activities more easily, hence making the execution of environmental regulations more tiresome (Talukdar \& Meisner, 2001: 830). Finally, Adewuyi (2016: 496) asserts that DPRI in the energy sector and/or energy-intensive products directly induce environmental damage; moreover, DPRI in these sectors accelerate pollution indirectly because their products may serve as inputs in other private sectors.

Even though opposing views exist on the environmental impact of DPRI, the majority of empirical studies show that DPRI accelerates environmental deterioration. Talukdar \& Meisner (2001) examined how DPRI affected carbon emissions in 44 developing countries by utilizing a reduced-form random-effects model for the 1987-1995 period. Their findings showed that DPRI significantly reduced carbon dioxide emissions. However, Adewuyi (2016) studied the same subject for selected 40 countries considering the 1990-2015 period, and their results from the modified heterogeneous panel data method showed that DPRI intensified carbon dioxide emissions in the selected countries. Hassan (2018) investigated the same issue for Malaysia for the 1976-2013 period by utilizing 
time series analysis. Their findings also indicated that DPRI in Malaysia increased carbon dioxide emissions both in the long-run and in the short-run.

As stated previously, there is no study empirically tested the impact of DPRI on environmental damage in Turkey. Nevertheless, one study which is conducted by Soytas \& Sari (2009) considered gross fixed capital formation (gfcf) in their models. Further, their causality analysis showed that gfcf increased carbon dioxide emissions in Turkey in the 1960-2000 period. Another study that might be somewhat related to the subject of this study belongs to Așicı (2015). Aş1c1 (2015) examined the sustainability of the Turkish economy for the 19952009 period via an input-output approach by using sectoral data. Their findings implied that sectoral shares in growth shifted to more energy-intensive and polluting industries in the 2003-09 period, compared to the 1995-2002 period.

Another perspective on the DPRI-environment nexus stems from the stringency of environmental policies. Accordingly, the Porter hypothesis postulates that stricter environmental regulations, given that they are also effective, can promote technological innovation and efficiency via fostering competition. Further, this situation not only benefits DPRI, but also improves social well-being through improving environmental conditions (see Du et al., 2018; Porter \& Linde, 1995; Wagner, 2003). Although Du et al. (2018) empirically confirmed the Porter hypothesis by finding that environmental regulations positively impact innovations and investment efficiency, Rondinelli \& Vastag (1998), in their case study, showed that strict environmental regulations are not needed for firms to implement environmentally benign production measures.

Although the main aim of this research to study the direct impact of DPRI on Turkey's environmental deterioration, it can be beneficial and provide some insights to observe the relative strictness of environmental policies in Turkey. In this respect, figure 2 shows the environmental policy stringency indices of Turkey and selected OECD countries.

Figure 2 shows that the stringency of environmental policies in Turkey has always been lower than the average of the selected OECD economies. This situation implies that environmental policies are not stringent enough in Turkey. Given the facts that both DPRI and environmental damage increased in Tukey (figure 1) and Turkey's environmental policies are not stringent (figure 2), we can suggest that Turkey's DPRI resulted in environmental damage. Nonetheless, to confirm this suggestion, proper time-series analyses should be applied, and this is done in the following sections of this research. 


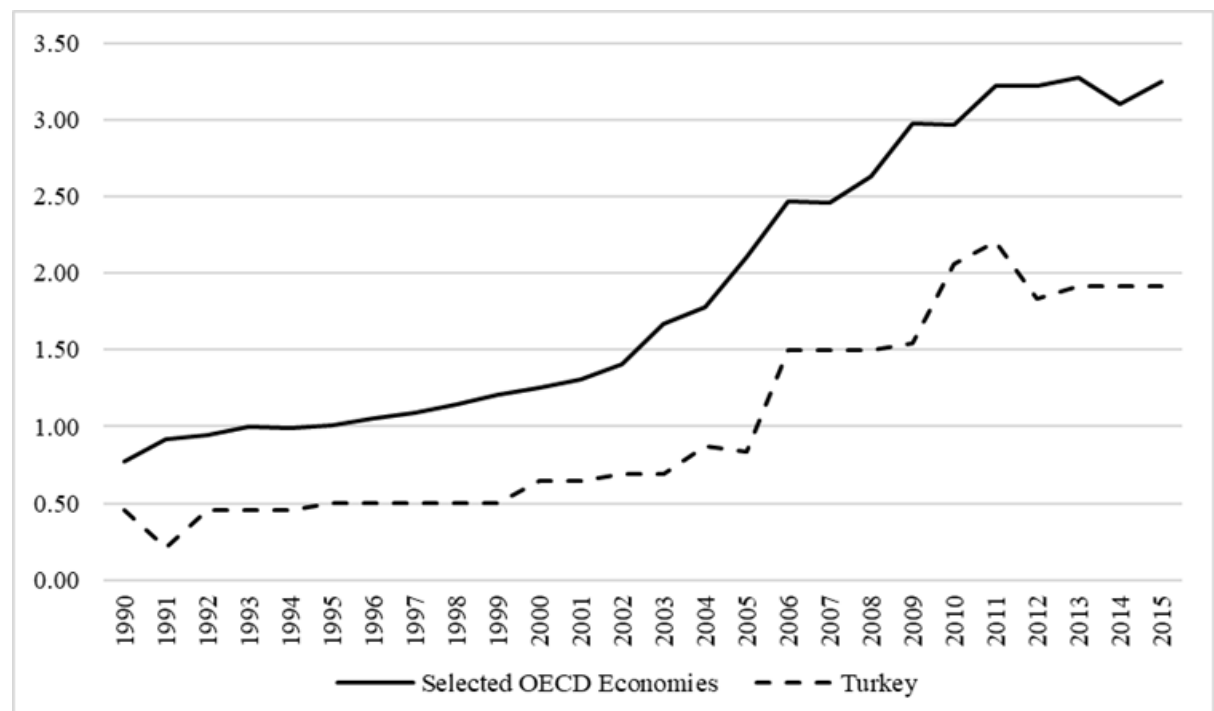

Figure 2: Environmental Policy Stringencies in Turkey and Selected OECD Economies (1990-2015)

Notes: selected OECD countries are Australia, Canada, France, Germany, Italy, Japan, Korea, the United Kingdom, and the United States. Selection is solely based on data availability. OECD: Organization for Economic Co-operation and Development. Data source: https://stats.oecd.org/\# (accessed on 03.02.2021).

\section{MODELS, DATA, AND METHODS}

\subsection{Models and Data}

This research employs yearly data spanning from 1975 to 2017. Data availability is the main reason for selecting this sample period. Based on the used environmental degradation indicators, namely ecological and carbon footprints, the following two (parsimonious) models are proposed:

$$
\begin{aligned}
& \text { lefpc } c_{t}=\beta_{1}+\beta_{2} \operatorname{lgdppc}_{t}+\beta_{3} \text { lpencpc }_{r}+\beta_{4} \text { ldpri }_{t}+u_{t} \\
& \text { lcfpc } c_{t}=\beta_{5}+\beta_{6} \text { lgdppc }_{t}+\beta_{7} \text { lpencp }_{r}+\beta_{8} \text { ldpri }_{t}+u_{t}
\end{aligned}
$$

In equations (1) and (2), the " $l$ " symbol shows that the variables are employed in logarithmic form. Moreover, $\beta_{1, \ldots, 8}$ present the coefficients to be 
estimated. Summary statistics for the variables are provided in the appendix section. Additionally, the definitions and sources of the utilized time series are given in Table 1.

Table 1: Definition of the Variables

\begin{tabular}{|c|c|c|}
\hline Symbols & Definition & Source \\
\hline efpc & $\begin{array}{l}\text { The ecological footprint of } \\
\text { consumption (per person, global } \\
\text { hectare -gha) }\end{array}$ & \multirow{2}{*}{$\begin{array}{l}\text { Global Footprint Network } \\
\text { (Global Footprint Network National } \\
\text { Footprint Accounts, 2020) }\end{array}$} \\
\hline$c f p c$ & $\begin{array}{l}\text { The carbon footprint (per person, } \\
\text { global hectare-gha) }\end{array}$ & \\
\hline$g d p p c$ & $\begin{array}{l}\text { Gross domestic product (GDP } \\
\text { per capita, constant } 2010 \text { US\$) }\end{array}$ & $\begin{array}{l}\text { World Development Indicators } \\
\text { (The World Bank, 2020) }\end{array}$ \\
\hline pencpc & $\begin{array}{l}\text { Primary energy consumption (per } \\
\text { capita, gigajoule) }\end{array}$ & $\begin{array}{l}\text { British Petroleum (BP) database } \\
(\mathrm{BP}, 2020)\end{array}$ \\
\hline$d p r i^{\dagger}$ & $\begin{array}{l}\text { Domestic private investment } \\
\text { (gross fixed, } \% \text { of GDP) }\end{array}$ & $\begin{array}{l}\text { The Presidency of Strategy and } \\
\text { Budget (Economic and Social } \\
\text { Indicators - Presidency of the } \\
\text { Republic of Turkey - the Presidency } \\
\text { of Strategy and Budget, 2020) }\end{array}$ \\
\hline
\end{tabular}

$\dagger$ : Data for 2017 is retrieved from the "2019 Presidency Annual Program"

(https://www.sbb.gov.tr/wp

content/uploads/2018/11/2019 Yili_Cumhurbaskanligi_Yillik_Programi.pdf, accessed on 24/01/2021).

\subsection{The Unit-root Test with a Fourier Approximation}

Besides frequently used the augmented Dickey-Fuller (ADF) test of Dickey \& Fuller (1981), this research also utilizes the Fourier approximated generalized least squares test (also known as the Fourier-GLS test) of Rodrigues \& Taylor (2012) to investigate the stationarity properties of the variables in the proposed models. The principal reason for employing such a test is that -unlike other unit-root tests which also account for structural changes (e.g., Narayan \& Popp (2010) and Zivot \& Andrews (2002))- there is no requirement to know the exact date and/or the number of structural breaks beforehand and that it is more feasible as its numerical procedures are relatively less cumbersome (Nazlioglu et al., 2016: 172; Rodrigues \& Taylor, 2012: 737).

Beginning from the data generating process (DGP) which is presented in equation (3), the essence of the Fourier-GLS test can be summarized as follows: 


$$
\begin{gathered}
y_{t}=a_{1}+a_{2} t+a_{3} \sin \left(\frac{2 \pi k t}{T}\right)+a_{4} \cos \left(\frac{2 \pi k t}{T}\right)+z_{t}, \quad t=1, \ldots, T \\
z_{t}=\delta z_{t-1}+e_{t}
\end{gathered}
$$

In equation (3), the terms $k, t$, and $T$ present a fixed Fourier frequency, trend, and sample size, respectively. In equation (4), $e_{t} \sim \operatorname{iid}\left(0, \sigma^{2}\right)$ and the first condition, which is $z_{0}$, is a random variable with an $O_{p}(1)$ characteristic. To examine the stationarity properties of the selected time series, the null hypothesis of $H_{0}: \delta=1$, opposed to its alternative $H_{a}:|\delta|<1$, should be tested (Rodrigues \& Taylor, 2012: 737-738). If the $H_{0}$ is rejected, then it is confirmed that the variable of interest is stationary (for further details, see Rodrigues \& Taylor, 2012).

\subsection{The Cointegration Test with a Fourier Component}

Similar to the Fourier-GLS unit-root test, the cointegration (CI) test employed in this research also includes a Fourier component to account for the (unknown) structural changes. The test is developed by Tsong et al. (2016), and it is a generalized version of the CI test of Shin (1994). It improves the CI test of Shin (1994) by permitting a Fourier component in its deterministic trend (Tsong et al., 2016: 1087).

The crux of this approach, starting from the CI regression shown in equation (5), can be stated as follows:

$$
y_{t}=d_{t}+x_{t}^{\prime} \beta+\varphi_{t}, \quad t=1,2,3, \ldots, T
$$

In equation (5), $\varphi_{t}=\gamma_{t}+v_{I t}, \gamma_{t}=\gamma_{t-1}+u_{t}$ in which $\gamma_{0}=0, x_{t}=x_{t-1}+v_{2 t}$, and $u_{t} \sim \operatorname{iid}\left(0, \sigma_{u}{ }^{2}\right)$. Thus, $\gamma_{t}$ is a random process with zero mean. Further, the deterministic component $\left(d_{t}\right)$ in equation (5) can be shown in equation (6) as:

$$
d_{t}=\sum_{i=0}^{m} \delta_{i} t^{i}+f_{t}, \quad \text { with } m=0 \text { or } 1
$$

Also, $f_{t}$ in equation (6) is defined as:

$$
f_{t}=a_{k} \sin \left(\frac{2 \pi k t}{T}\right)+\beta_{k} \cos \left(\frac{2 \pi k t}{T}\right)
$$

Additionally, in the Tsong et al. (2016) study, $B(t) \approx f_{t}$ and $B(t)$ serve as a function with an unidentified form of structural shifts/breaks. As the $p$-vector $v_{2 t}$ and the scalar $v_{1 t}$ are stationary, both $x_{t}$ and $y_{t}$ processes are integrated of order one (i.e., $I(1)$ ). Evidently, given that $\sigma_{u}{ }^{2}=0, \varphi_{t}=v_{I t}$ becomes a stationary process, indicating that $x_{t}$ and $y_{t}$ are associated in the long-run (LR) (i.e., cointegrated). Correspondingly, to study the existence of $\mathrm{CI}$ among the selected variables in 
both proposed models, the following null hypothesis of CI against its alternative hypothesis of no-CI should be tested:

$$
H_{0}: \sigma_{u}^{2}=0 \text { vs. } H_{A}: \sigma_{u}^{2}>0
$$

In short, as shown in equation (8), if the null hypothesis $\left(H_{0}\right)$ is not rejected, then it will be decided that the variables in the models are cointegrated. On the contrary, if the $H_{0}$ is rejected, the time series in the models are not cointegrated (Tsong et al., 2016: 1087-1088). In this research, the test statistic retrieved from this procedure is shown as " $C I_{\text {Fourier-test stat.". }}$

However, to employ the testing procedure explained above, the inclusion of the Fourier terms (shown in equation (7)) into the deterministic component should be justified. As Tsong et al. (2016) propose, this justification process can be executed via an F-test which tests the $H_{0}: \alpha_{k}=\beta_{k}=0$ against the $H_{1}: \alpha_{k} \neq \beta_{k} \neq 0$. The proposed F-test in Tsong et al. (2016) can be summarized in the next equations:

In which

$$
F^{m}\left(k^{*}\right)=\max _{k \in\{1,2,3\}} F^{m}(k)
$$

$$
F^{m}(k)=\frac{\left(S S R_{0}^{m}-S S R_{1}^{m}(k)\right) / 2}{\operatorname{SSR}_{1}^{m}(k) /(T-q)}
$$

In equation (10), $S S R_{0}{ }^{m}$ and $\operatorname{SSR}_{I}{ }^{m}(k)$ show the sum of squared residuals for the regressions without and with the Fourier components, respectively, and $q$ shows the number of regressors under the $H_{l}$. If the $F^{m}\left(k^{*}\right)$-test statistic is significant, then the Fourier component(s) should be included in the CI testing process (Tsong et al., 2016: 1092-1093).

\subsection{Robustness Check for the Cointegration Procedure and Estimating the Models: the ARDL Approach}

This research complements the Fourier augmented CI test of Tsong et al. (2016) using the ARDL bounds testing approach to cointegration proposed by Pesaran et al. (2001). Moreover, the same methodology is also utilized to estimate the long-run and the short-run coefficients that show how the selected regressors (lgdppc, lpencpc, and ldpi) influence the dependent variable(s) (i.e. lefpc and $l c f p c$ ). Execution of this method relies on estimating the following (error correction) model, which is based on equation $(1)^{2}$ :

\footnotetext{
${ }^{2}$ This method is only presented for the lefpc model; the process is the same for the lcfpc model.
} 


$$
\begin{gathered}
\Delta l e f p c_{t}=\rho_{1}+\sum_{i=1}^{p} \rho_{i} \Delta l e f p c_{t-i}+\sum_{m=0}^{u} \rho_{m} \Delta \operatorname{lgdppc}_{t-m}+\sum_{z=0}^{b} \rho_{z} \text { Llpencp }_{t-z}+\sum_{j=0}^{q} \rho_{j} \Delta \text { ldpri }_{t-j}+ \\
\delta_{1} \text { lefpc }_{t-1}+\delta_{2} \text { lgdppc }_{t-1}+\delta_{3} \text { lpencp }_{t-1}+\delta_{4} \text { ldpri }_{t-1}+\mu_{t}
\end{gathered}
$$

In equation (11), $\delta_{1, \ldots 4}$ show the coefficients to be estimated for the longrun impacts. Further, $\rho_{i, m, z, j}$ show the short-run parameters to be estimated, and varying lag-lengths can be assigned to each selected variable. To confirm the CI, significance of the two bounds tests (F-test and t-test) should be validated. In the F-test, $H_{0}: \delta_{1}=\ldots=\delta_{4}=0$ against $H_{A}: \delta_{l} \neq \ldots \neq \delta_{4} \neq 0$ is tested. If the calculated Fstatistic is higher than the upper-bound $(U B)$ critical value that is also proposed by Pesaran et al. (2001), then the significance of the F-test will be confirmed. In the t-test, only the coefficient of the lagged dependent variable is tested for significance: $H_{0}: \delta_{I}=0$ against $H_{A}: \delta_{I} \neq 0$. Similar to the F-test, given that the calculated t-statistic, in absolute values, higher than its corresponding UB critical value, then the significance of the $\mathrm{t}$-test will be confirmed. If both tests ( $\mathrm{F}$ - and $\mathrm{t}$ tests) are significant, then it will be confirmed that the variables in the model(s) are cointegrated.

Besides equation (11), the following (error correction) equation is simultaneously run to estimate the error correction term's and the short-run coefficients:

$$
\Delta l e f p c_{t}=\varphi_{1}+\sum_{i=1}^{p} \rho_{i} \Delta l e f p c_{t-i}+\sum_{m=0}^{u} \rho_{m} \Delta l g d p p c_{t-m}+\sum_{z=0}^{b} \rho_{z} \Delta \operatorname{llpencpc}_{t-z}+\sum_{j=0}^{q} \rho_{j} \Delta l d p r i_{t-1}+\epsilon_{t}+
$$

\section{FINDINGS AND DISCUSSION}

In this section, the findings of this research are shown. Firstly, the unitroot properties of the selected time series are presented in Table 2: 
Table 2: Results of the Stationarity Tests

\begin{tabular}{|c|c|c|c|c|c|c|}
\hline \multicolumn{4}{|c|}{ ADF } & \multicolumn{3}{|c|}{ Fourier-GLS } \\
\hline variables & \multicolumn{2}{|c|}{ statistic } & $l$ & statistic & $k$ & $l$ \\
\hline lefpc & \multicolumn{2}{|c|}{$-4.036 * *$} & 1 & -3.571 & 1 & 1 \\
\hline$l c f p c$ & \multicolumn{2}{|c|}{$-3.997 * *$} & 1 & -3.393 & 1 & 1 \\
\hline $\lg d p p c$ & \multicolumn{2}{|c|}{-2.433} & 0 & -3.336 & 1 & 2 \\
\hline lpencpc & \multicolumn{2}{|c|}{-2.643} & 0 & -3.498 & 1 & 2 \\
\hline ldpri & \multicolumn{2}{|c|}{$-4.040 * *$} & 2 & -3.537 & 1 & 2 \\
\hline \multirow{2}{*}{$C V S$} & $1 \%$ & $5 \%$ & $10 \%$ & $1 \%$ & $5 \%$ & $10 \%$ \\
\hline & -4.150 & -3.500 & -3.180 & -4.771 & -4.175 & -3.879 \\
\hline$\Delta l e f p c$ & \multicolumn{2}{|c|}{$-6.722 * * *$} & 1 & $-4.153 * * *$ & 1 & 2 \\
\hline$\Delta l c f p c$ & \multicolumn{2}{|c|}{$-4.192 * * *$} & 2 & $-4.007 * * *$ & 1 & 2 \\
\hline$\Delta \lg d p p c$ & \multicolumn{2}{|c|}{$-6.040 * * *$} & 0 & $-6.208 * * *$ & 1 & 0 \\
\hline Slpencpc & \multicolumn{2}{|c|}{$-3.890 * * *$} & 2 & $-4.004 * * *$ & 1 & 2 \\
\hline$\Delta l d p r i$ & \multicolumn{2}{|c|}{$-6.089 * * *$} & 0 & $-3.979 * * *$ & 1 & 1 \\
\hline$C V S$ & $\begin{array}{c}1 \% \\
-3.590\end{array}$ & $\begin{array}{c}5 \% \\
-2.930\end{array}$ & $\begin{array}{c}10 \% \\
-2.600\end{array}$ & $\begin{array}{c}1 \% \\
-3.911\end{array}$ & $\begin{array}{c}5 \% \\
-3.294\end{array}$ & $\begin{array}{c}10 \% \\
-2.328\end{array}$ \\
\hline
\end{tabular}

Notes: $* *$ and $* * *$ indicate significance at $5 \%$ and $1 \%$ levels, respectively. $k$ : frequency, $l$ : optimal lag length. CVs: critical values. The maximum lag length is set to be 2. Lag length selection is based on the Akaike information criterion (AIC). The ADF test equations include time trend and constant in levels and only constant in the first differences. Besides the Fourier terms, the Fourier-GLS test equations include constant and time trend in levels but contain constant in the first differences.

According to the ADF test results in table 2, environmental sustainability indicators (lefpc and lcfpc) and the DPRI variable (ldpri) do not have a unit-root at $5 \%$ significance level; in other words, they are stationary (i.e., $I(0))$. However, at $1 \%$ significance level, all the selected variables become stationary in their first differences; thus, they are $I(1)$. Fourier-GLS unit-root test findings display that none of the variables is $I(0)$; however, all of them become stationary (i.e., $I(1))$ in their first differences. As none of the selected variables is I(2), the selected CI tests can be applied to the proposed models to examine whether cointegration exists. The results regarding the CI tests are reported in table 3 : 
Table 3: Results of the Cointegration Tests

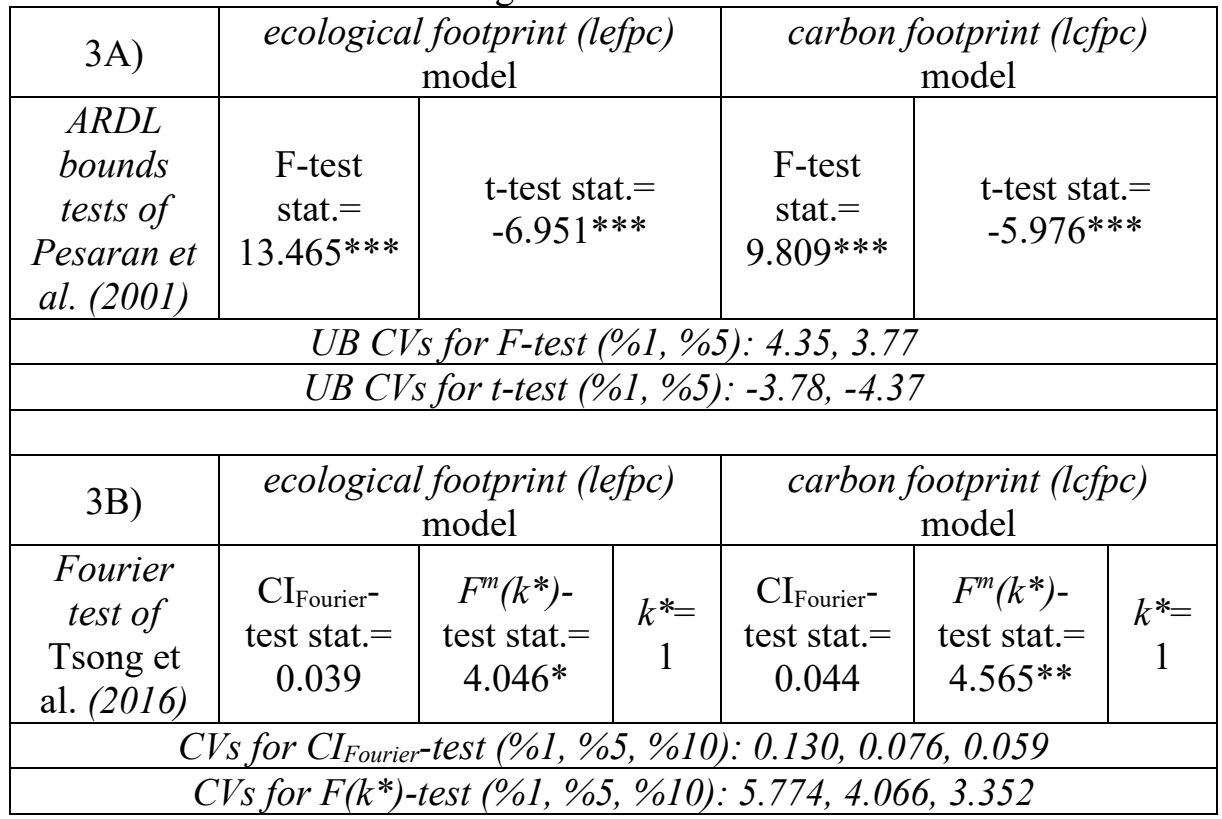

Notes: $k^{*}$ is the optimum frequency. CVs: critical values. UB: upper bound. For the ARDL bounds tests, Case-III, which includes an unrestricted constant without a trend is chosen. Fourier cointegration test equation includes the Fourier component and a constant. The Fourier (cointegration) test results are based on the dynamic ordinary least squares (DOLS) estimates. The critical values for the ARDL bounds tests and the Fourier-CI tests are retrieved from Pesaran et al. (2001) and Tsong et al. (2016), respectively. ${ }^{*}, *$ and $* * *$ for test statistics show significance at $10 \%, 5 \%$ and $1 \%$ levels, respectively.

Panel 3B of table 3 presents the Fourier-CI test results for both models. Both test-statistics $\left(\mathrm{CI}_{\text {Fourier-test stat. }}\right)$ are not significant. This indicates that the null hypothesis of cointegration cannot be rejected for both models, viz. long-run association exists among the selected variables in each model. In addition, both $F^{m}\left(k^{*}\right)$-tests, which show whether the Fourier terms should be included in the CI equations, are significant. This result also implies that the suitable method is chosen for testing the $\mathrm{CI}$ among the variables.

Additionally, panel 3A of table 3 reports the ARDL bounds test results. Both tests ( $\mathrm{F}$ and $\mathrm{t}$ ) for both models are statistically significant at $1 \%$ level. This evidence also confirms the results of the Fourier-CI test results (see panel 3B). To summarize, both CI-tests confirm that a long-run association exists among the 
variables in both models. Therefore, how independent variables affect environmental damage indicators can be observed. For this reason, the ARDL estimations of both models are shown in table 4.

According to the long-run (LR) findings that are presented in panel 4A of table 4, income per capita (lgdppc), primary energy usage per capita (lencpc), and DPRI (ldpri) have positive coefficients, yet only lpencpc and ldpri have significant LR impacts on the ecological footprint (lefpc) and carbon footprint $(l c f p c)$. Our LR results show that a $1 \%$ increase in primary energy use results in $0.27 \%$ and $0.67 \%$ increase in lefpc and $l c f p c$, respectively. This finding is not surprising since primary energy use in Turkey mainly consists of fossil-fuels ${ }^{3}$. Another significant LR finding is about DPRI in Turkey. DPRI increases both environmental degradation indicators in Turkey in the LR. For example, a $1 \%$ change (increase) in ldpri corresponds to a $0.12 \%$ change (increase) in lefpc, and to a $0.15 \%$ change (increase) in $l c f p c$. In short, these results illustrate that DPRI in Turkey induces environmental damage in the LR. This finding correlates with our expectations and is in line with the findings of Adewuyi (2016), Hassan (2018), and Soytas \& Sari (2009), yet contradicts the result in Talukdar \& Meisner (2001).

${ }^{3}$ According to BP (2020) statistics. 
Table 4: Estimation Results

\begin{tabular}{|c|c|c|}
\hline \multicolumn{3}{|l|}{ 4A) LR coefficients } \\
\hline regressors & lefpc model & lcfpc model \\
\hline \multirow{2}{*}{$\operatorname{lgdppc}$} & 0.1158 & 0.1721 \\
\hline & $(0.1698)$ & $(0.2667)$ \\
\hline \multirow{2}{*}{ lpencpc } & $0.2652 * * *$ & $0.6748 * * *$ \\
\hline & $(0.0003)$ & $(0.0000)$ \\
\hline \multirow{2}{*}{ ldpri } & $0.1218 * *$ & $0.1429 *$ \\
\hline & $(0.0110)$ & $(0.0881)$ \\
\hline \multicolumn{3}{|l|}{ 4B) SR coefficients } \\
\hline \multirow{2}{*}{ constant } & $-1.4910 * * *$ & $-3.5057 * * *$ \\
\hline & $(0.000)$ & $(0.000)$ \\
\hline \multirow{2}{*}{$\Delta \lg d p p c_{t}$} & $0.5409 * * *$ & $0.6888 * * *$ \\
\hline & $(0.0008)$ & $(0.0013)$ \\
\hline \multirow{2}{*}{$e c t_{t-1}$} & $-1.0380 * * *$ & $-0.8182 * * *$ \\
\hline & $(0.000)$ & $(0.000)$ \\
\hline \multicolumn{3}{|l|}{ 4C) Diagnostics } \\
\hline & $\begin{array}{l}\text { test stat. } \\
\text { (p-value) }\end{array}$ & $\begin{array}{l}\text { test stat. } \\
\text { (p-value })\end{array}$ \\
\hline \multirow{2}{*}{$B G$ serial corr. } & 1.5865 & 0.8481 \\
\hline & $(0.2078)$ & $(0.3571)$ \\
\hline \multirow{2}{*}{ Ramsey RESET } & 0.1677 & 0.3455 \\
\hline & $(0.6847)$ & $(0.5604)$ \\
\hline \multirow{2}{*}{$J B$ Normality } & 1.4290 & 1.7684 \\
\hline & $(0.4894)$ & $(0.4130)$ \\
\hline \multirow{2}{*}{$A R C H$} & 0.5994 & 0.2096 \\
\hline & $(0.4388)$ & $(0.6471)$ \\
\hline CUSUM \& CUSUMSQ & stable \& stable & stable \& stable \\
\hline$R^{2}$ & 0.9681 & 0.9840 \\
\hline Adj. $R^{2}$ & 0.9637 & 0.9819 \\
\hline F-stat. & $218.474 * * *$ & $444.835 * * *$ \\
\hline
\end{tabular}

Notes: $* * *$, and $* * *$ present significance at $1 \%, 5 \%$ and $10 \%$ levels, respectively. Values in the parentheses are p-values. The maximum lag length is set as 1 . Lag length selection is based on the Akaike information criterion $(A I C)$. Optimum lags for the variables are $(1,1,0,0)$ for both models. BG: Breusch-Godfrey, JB: Jarque-Bera, ARCH: autoregressive conditional heteroskedasticity, LR: long-run, and SR: shortrun.

Panel 4B of table 4 shows the short-run (SR) findings. These findings 
show that per capita income $(\lg d p p c)$ imposes a positive significant impact on ecological and carbon footprints. In numerical terms, a $1 \%$ increase (decrease) in per-person income in Turkey intensifies (curtails) the ecological footprint by $0.54 \%$ and carbon footprint by $0.69 \%$. These results imply that growth, which might be partly induced by DPRI, is harmful to environmental sustainability. Further, in the same panel, the coefficients of the error correction terms for both models are also reported. Both coefficients are significant and include the expected negative signs.

Panel 4C of table 4 takes up the diagnostic tests. These tests indicate that both models are econometrically appropriate and do not contain any statistical issues that might distort the estimation results. Moreover, the stability tests (CUSUM and CUSUMSQ ${ }^{4}$ ) indicate that the estimated parameters are stable through the sample period. This evidence indicates that these results can be employed to propound future policy recommendations (Onafowora \& Owoye, 2014: 56).

\section{CONCLUSION}

This research examines if DPRI intensifies carbon and ecological footprints in Turkey for the 1975-2017 sample period. In this research, the Fourier augmented unit-root, and CI tests are employed to account for unknown shifts in the employed time series and models. Additionally, the ARDL approach is utilized to investigate the dynamic LR and SR associations between the variables. The main findings are as follows: (i) there exists a long-run association among the employed time series in both proposed models, (ii) in the LR, DPRI contributes to environmental damage in Turkey by increasing both ecological, and carbon footprints, (iii) primary energy use is another factor contributing to the LR environmental damage in Turkey, (iv) growth reduces the environmental quality in Turkey in the SR. In the light of these results, some policy recommendations can be proposed.

First, because DPRI in Turkey worsens environmental degradation in the LR, and Turkey's environmental regulation stringency is rather low, it is imperative to improve the stringency of environmental policies in Turkey. This may increase energy efficiency and technical innovations in Turkish private sectors, thus curtailing DPRI's negative impact on the environment. Furthermore, Altuğ \& Zenginobuz (2009: 139) state that long-term sustainable development in Turkey relies on productivity-improving investments. In order to incentivize

${ }^{4}$ Graphs for these tests are given in the appendix section of this research. 
productivity and efficiency in DPRI, necessary amendments should be applied by government officials.

Second, both primary energy use and growth induce environmental deterioration in Turkey in the LR and the SR, respectively. In this regard, Turkey needs its private sector to promote efficiency and innovations and invest in renewable energy sources as well. Necessary incentives and promotions should be put in motion in Turkey to induce private entrepreneurs to make such investment decisions. Also, to induce such environmentally-friendly investments, macroeconomic instability/uncertainty should be kept under control in Turkey because macroeconomic instability/uncertainty is found to be negatively associated with investments (see Güney, 2020; Ismihan et al., 2005).

Finally, shifting from fossil fuels to clean energy would curb DPRI's negative impact on the environment and mitigate primary energy use's negative impact. Empirical evidence by Karasoy (2019) on Turkey shows that shifting from non-renewable energy to renewable energy curtails environmental pollution. This shift could also limit economic growth's negative SR impact on environmental degradation. Subsequently, environmental conditions would improve in Turkey.

Further research may focus on a sectoral analysis of the private sector. A sectoral analysis of private investment may provide a clearer picture of which sectors induce/reduce environmental damage in Turkey and other developing countries. Finally, by this approach, more in-depth and sector-specific policy suggestions can be offered.

\section{CONFLICT OF INTEREST STATEMENT}

There is no conflict of interest between the authors (single author).

\section{FUNDING ACKNOWLEDGEMENTS}

This research received no funding from any agency in the public, commercial, or not-for-profit sectors.

\section{AUTHOR CONTRIBUTIONS}

All the contributions are made by AK.

\section{PROPERTY COPYRIGHTS}

9. ETHICS COMMITTEE STATEMENT AND INTELLECTUAL

Ethics committee principles are strictly followed in this study. Necessary permissions are obtained in accordance with the intellectual property copyrights principle. 


\section{REFERENCES}

Adewuyi, A. O. (2016). Effects of public and private expenditures on environmental pollution: A dynamic heterogeneous panel data analysis. Renewable and Sustainable Energy Reviews, 65, 489-506. https://doi.org/10.1016/j.rser.2016.06.090

Akçay, S., \& Karasoy, A. (2020). Determinants of private investments in Turkey: Examining the role of democracy. Review of Economic Perspectives, 20(1), 23-49. https://doi.org/10.2478/revecp-2020-0002

Altuğ, S., \& Zenginobuz, Ü. (2009). What has been the role of investment in Turkey's growth performance? In Z. Öniş \& F. Şenses (Eds.), Turkey and the Global Economy (1st ed., pp. 123-144). Routledge. https://www.taylorfrancis.com/chapters/role-investment-turkey-growthperformance-sumru-altuğ-ünal-zenginobuz-ziya-onis-fikretsenses/e/10.4324/9780203867426-13?context=ubx\&refId=11a646c1-1424-4aee$8 \mathrm{e} 2 \mathrm{e}-59 \mathrm{~b} 38 \mathrm{ccf} 1 \mathrm{~b} 4 \mathrm{c}$

Aşı1c1, A. A. (2015). On the sustainability of the economic growth path of Turkey: 19952009. Renewable and Sustainable Energy Reviews, 52, 1731-1741. https://doi.org/10.1016/j.rser.2015.07.192

Ayeni, R. K. (2020). Determinants of private sector investment in a less developed country: a case of the Gambia. Cogent Economics \& Finance, 8(1), 1794279. https://doi.org/10.1080/23322039.2020.1794279

BP. (2020). BP Statistical Review of World Energy 2020. https://www.bp.com/content/dam/bp/businesssites/en/global/corporate/pdfs/energy-economics/statistical-review/bp-statsreview-2020-full-report.pdf

Dickey, D. A., \& Fuller, W. A. (1981). Likelihood Ratio Statistics for Autoregressive Time Series with a Unit Root. Econometrica, 49(4), 1057-1072. https://doi.org/10.2307/1912517

Du, Y., Jiang, L., \& Zhou, Y. (2018). The Impact of Environmental Regulations on Private Investment Efficiency. 5th International Conference on Industrial Economics System and Industrial Security Engineering (IEIS), 1-6. https://doi.org/10.1109/IEIS.2018.8598149

Economic and Social Indicators - Presidency of the Republic of Turkey - the Presidency of Strategy and Budget. (2020). https://www.sbb.gov.tr/ekonomik-ve-sosyalgostergeler/\#1540021349032-1be70108-294c

Global Footprint Network National Footprint Accounts. (2020). http://data.footprintnetwork.org

Güney, P. Ö. (2020). Macroeconomic uncertainty and investment relationship for Turkey. Economic Journal of Emerging Markets, 12(2), 151-166. https://doi.org/10.20885/ejem.vol12.iss2.art3 
Hassan, S. (2018). Dynamic Impact of Energy Consumption, Private Investment and Financial Development on Environmental Pollutions: Evidence from Malaysia. International Journal of Energy Economics and Policy, 8(4), 63-69. http:www.econjournals.com

Ikpesu, F., Vincent, O., Dakare, O., \& Nsiah, C. (2019). Growth effect of trade and investment in Sub-Saharan Africa countries: Empirical insight from panel corrected standard error (PCSE) technique. Cogent Economics \& Finance, 7(1), 1607127. https://doi.org/10.1080/23322039.2019.1607127

Ismihan, M., Metin-Ozcan, K., \& Tansel, A. (2005). The role of macroeconomic instability in public and private capital accumulation and growth: the case of Turkey 1963-1999. Applied Economics, 37(2), 239-251. https://doi.org/10.1080/0003684042000286115

Karasoy, A. (2019). Drivers of carbon emissions in Turkey: considering asymmetric impacts. Environmental Science and Pollution Research, 26(9), 9219-9231. https://doi.org/10.1007/s11356-019-04354-4

Khan, M. S., \& Reinhart, C. M. (1990). Private investment and economic growth in developing countries. World Development, 18(1), 19-27. https://doi.org/10.1016/0305-750X(90)90100-C

Makuyana, G., \& Odhiambo, N. M. (2019). Public and private investment and economic growth in Malawi: an ARDL-bounds testing approach. Economic ResearchEkonomska Istraživanja, 32(1), 673-689. https://doi.org/10.1080/1331677X.2019.1578677

Narayan, P. K., \& Popp, S. (2010). A new unit root test with two structural breaks in level and slope at unknown time. Journal of Applied Statistics, 37(9), 1425-1438. https://doi.org/10.1080/02664760903039883

Nazlioglu, S., Gormus, N. A., \& Soytas, U. (2016). Oil prices and real estate investment trusts (REITs): Gradual-shift causality and volatility transmission analysis. Energy Economics, 60, 168-175. https://doi.org/10.1016/j.eneco.2016.09.009

Onafowora, O. A., \& Owoye, O. (2014). Bounds testing approach to analysis of the environment Kuznets curve hypothesis. Energy Economics, 44, 47-62. https://doi.org/10.1016/j.eneco.2014.03.025

Pesaran, M. H., Shin, Y., \& Smith, R. J. (2001). Bounds testing approaches to the analysis of level relationships. Journal of Applied Econometrics, 16(3), 289-326. https://doi.org/10.1002/jae.616

Porter, M. E., \& Linde, C. van der. (1995). Toward a New Conception of the Environment-Competitiveness Relationship. Journal of Economic Perspectives, 9(4), 97-118. https://doi.org/10.1257/jep.9.4.97

Rodrigues, P. M. M., \& Taylor, A. M. R. (2012). The Flexible Fourier Form and Local Generalised Least Squares De-trended Unit Root Tests. Oxford Bulletin of Economics and Statistics, 74(5), 736-759. https://doi.org/10.1111/j.14680084.2011.00665.x 
Rondinelli, D. A., \& Vastag, G. (1998). Private investment and environmental protection: Alcoa-Köfem's Strategy in Hungary. European Management Journal, 16(4), 422 430. https://doi.org/10.1016/S0263-2373(98)00019-X

Sallam, S. S. (2019). Determinants of private investment in Egypt: an empirical analysis. Review of Economics and Political Science, 4(3), 257-266. https://doi.org/10.1108/REPS-12-2018-0043

Shabbir, M. S., Bashir, M., Abbasi, H. M., Yahya, G., \& Abbasi, B. A. (2020). Effect of domestic and foreign private investment on economic growth of Pakistan. Transnational Corporations Review, 1-13. https://doi.org/10.1080/19186444.2020.1858676

Shin, Y. (1994). A Residual-Based Test of the Null of Cointegration Against the Alternative of No Cointegration. Econometric Theory, 10(1), 91-115. https://doi.org/10.1017/S0266466600008240

Soytas, U., \& Sari, R. (2009). Energy consumption, economic growth, and carbon emissions: Challenges faced by an EU candidate member. Ecological Economics, 68(6), 1667-1675. https://doi.org/10.1016/j.ecolecon.2007.06.014

Talukdar, D., \& Meisner, C. M. (2001). Does the Private Sector Help or Hurt the Environment? Evidence from Carbon Dioxide Pollution in Developing Countries. World Development, 29(5), 827-840. https://doi.org/10.1016/S0305750X(01)00008-0

The World Bank. (2020). Dünya Kalkınma Göstergeleri. https://data.worldbank.org/datacatalog/world-development-indicators

Tsong, C.-C., Lee, C.-F., Tsai, L.-J., \& Hu, T.-C. (2016). The Fourier approximation and testing for the null of cointegration. Empirical Economics, 51(3), 1085-1113. https://doi.org/10.1007/s00181-015-1028-6

Wagner, M. (2003). The Porter Hypothesis Revisited: A Literature Review of Theoretical Models and Empirical Tests.

Zivot, E., \& Andrews, D. W. K. (2002). Further Evidence on the Great Crash, the OilPrice Shock, and the Unit-Root Hypothesis. Journal of Business \& Economic Statistics, 20(1), 25-44. https://doi.org/10.1198/073500102753410372

Zou, Y. (2006). Empirical studies on the relationship between public and private investment and GDP growth. Applied Economics, 38(11), 1259-1270. https://doi.org/10.1080/00036840500392649 
APPENDIX

Table A.1: Summary Statistics

\begin{tabular}{|cccccc|}
\hline & lefpc & lcfpc & lgdppc & lpencpc & ldpri \\
\hline Mean & 0.954 & 0.199 & 8.959 & 3.732 & 2.884 \\
Median & 0.969 & 0.207 & 8.940 & 3.779 & 2.862 \\
Maximum & 1.255 & 0.804 & 9.607 & 4.364 & 3.246 \\
Minimum & 0.704 & -0.328 & 8.511 & 3.059 & 2.493 \\
Std. Dev. & 0.171 & 0.349 & 0.326 & 0.382 & 0.238 \\
Skewness & 0.077 & 0.011 & 0.372 & -0.151 & -0.0001 \\
Kurtosis & 1.667 & 1.690 & 2.028 & 1.822 & 1.819 \\
\hline Jarque-Bera Normality & 3.227 & 3.0750 & 2.683 & 2.649 & 2.496 \\
Prob. & 0.199 & 0.215 & 0.261 & 0.266 & 0.287 \\
\hline
\end{tabular}
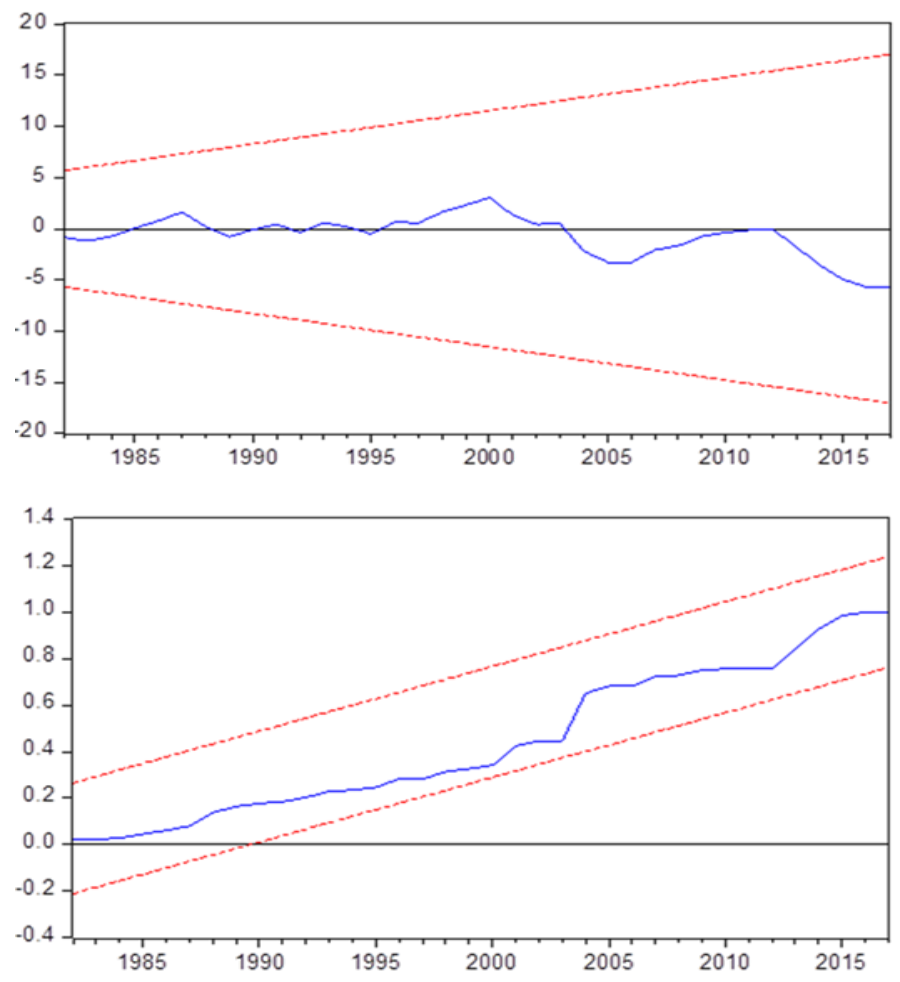

Figure A.1: CUSUM and CUSUMSQ Graphs for the lefpc Model 

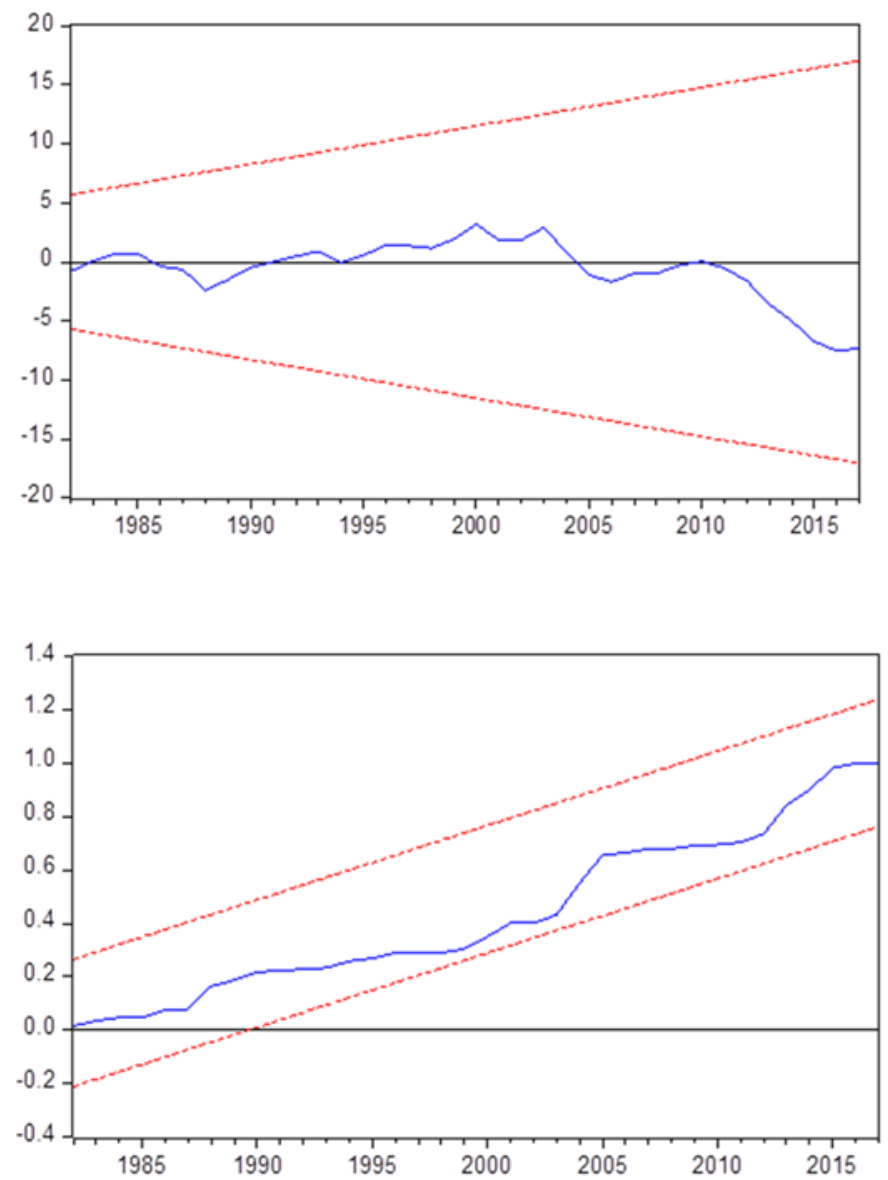

Figure A.2: CUSUM and CUSUMSQ Graphs for the $l c f p c$ Model 